

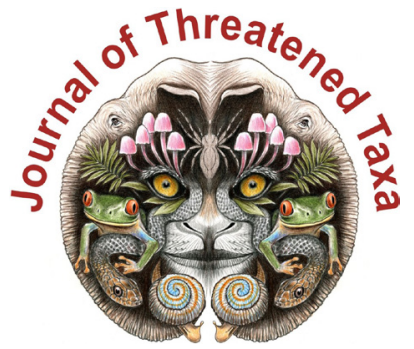

ISSN 0974-7907 (Online); ISSN $0974-7893$ (Print)

Publisher

Host

Wildlife Information Liaison Development Society

www.wild.zooreach.org

Zoo Outreach Organization www.zooreach.org

No. 12, Thiruvannamalai Nagar, Saravanampatti - Kalapatti Road, Saravanampatti, Coimbatore, Tamil Nadu 641035, India

Ph: +91 9385339863 | www.threatenedtaxa.org

Email: sanjay@threatenedtaxa.org

EDITORS

\section{Founder \& Chief Editor}

Dr. Sanjay Molur

Wildlife Information Liaison Development (WILD) Society \& Zoo Outreach Organization (ZOO),

12 Thiruvannamalai Nagar, Saravanampatti, Coimbatore, Tamil Nadu 641035, India

\section{Deputy Chief Editor}

Dr. Neelesh Dahanukar

Noida, Uttar Pradesh, India

\section{Managing Editor}

Mr. B. Ravichandran, WILD/ZOO, Coimbatore, India

\section{Associate Editors}

Dr. Mandar Paingankar, Government Science College Gadchiroli, Maharashtra 442605, India

Dr. Ulrike Streicher, Wildlife Veterinarian, Eugene, Oregon, USA

Ms. Priyanka Iyer, ZOO/WILD, Coimbatore, Tamil Nadu 641035, India

Dr. B.A. Daniel, ZOO/WILD, Coimbatore, Tamil Nadu 641035, India

\section{Editorial Board}

Dr. Russel Mittermeier

Executive Vice Chair, Conservation International, Arlington, Virginia 22202, USA

\section{Prof. Mewa Singh Ph.D., FASc, FNA, FNASc, FNAPsy}

Ramanna Fellow and Life-Long Distinguished Professor, Biopsychology Laboratory, and Institute of Excellence, University of Mysore, Mysuru, Karnataka 570006, India; Honorary Professor, Jawaharlal Nehru Centre for Advanced Scientific Research, Bangalore; and Adjunct Professor, National Institute of Advanced Studies, Bangalore

\section{Stephen D. Nash}

Scientific Illustrator, Conservation International, Dept. of Anatomical Sciences, Health Sciences Center, T-8, Room 045, Stony Brook University, Stony Brook, NY 11794-8081, USA

\section{Dr. Fred Pluthero}

Toronto, Canada

\section{Dr. Priya Davidar}

Sigur Nature Trust, Chadapatti, Mavinhalla PO, Nilgiris, Tamil Nadu 643223, India

\section{Dr. Martin Fisher}

Senior Associate Professor, Battcock Centre for Experimental Astrophysics, Cavendish

Laboratory, JJ Thomson Avenue, Cambridge CB3 OHE, UK

\section{Dr. John Fellowes}

Honorary Assistant Professor, The Kadoorie Institute, 8/F, T.T. Tsui Building, The University of Hong Kong, Pokfulam Road, Hong Kong

\section{Prof. Dr. Mirco Solé}

Universidade Estadual de Santa Cruz, Departamento de Ciências Biológicas, Vice-coordenado do Programa de Pós-Graduação em Zoologia, Rodovia Ilhéus/Itabuna, Km 16 (45662-000)

Salobrinho, Ilhéus - Bahia - Brasil

\section{Dr. Rajeev Raghavan}

Professor of Taxonomy, Kerala University of Fisheries \& Ocean Studies, Kochi, Kerala, India

\section{English Editors}

Mrs. Mira Bhojwani, Pune, India

Dr. Fred Pluthero, Toronto, Canad

Mr. P. Ilangovan, Chennai, India

Web Development

Mrs. Latha G. Ravikumar, ZOO/WILD, Coimbatore, India

\section{Typesetting}

Mr. Arul Jagadish, ZOO, Coimbatore, India

Mrs. Radhika, ZOO, Coimbatore, India

Mrs. Geetha, ZOO, Coimbatore India
Fundraising/Communications

Mrs. Payal B. Molur, Coimbatore, India

Subject Editors 2018-2020

Fungi

Dr. B. Shivaraju, Bengaluru, Karnataka, India

Dr. R.K. Verma, Tropical Forest Research Institute, Jabalpur, India

Dr. Vatsavaya S. Raju, Kakatiay University, Warangal, Andhra Pradesh, India

Dr. M. Krishnappa, Jnana Sahyadri, Kuvempu University, Shimoga, Karnataka, India

Dr. K.R. Sridhar, Mangalore University, Mangalagangotri, Mangalore, Karnataka, India

Dr. Gunjan Biswas, Vidyasagar University, Midnapore, West Bengal, India

\section{Plants}

Dr. G.P. Sinha, Botanical Survey of India, Allahabad, India

Dr. N.P. Balakrishnan, Ret. Joint Director, BSI, Coimbatore, India

Dr. Shonil Bhagwat, Open University and University of Oxford, UK

Prof. D.J. Bhat, Retd. Professor, Goa University, Goa, India

Dr. Ferdinando Boero, Università del Salento, Lecce, Italy

Dr. Dale R. Calder, Royal Ontaro Museum, Toronto, Ontario, Canada

Dr. Cleofas Cervancia, Univ. of Philippines Los Baños College Laguna, Philippines

Dr. F.B. Vincent Florens, University of Mauritius, Mauritius

Dr. Merlin Franco, Curtin University, Malaysia

Dr. V. Irudayaraj, St. Xavier's College, Palayamkottai, Tamil Nadu, India

Dr. B.S. Kholia, Botanical Survey of India, Gangtok, Sikkim, India

Dr. Pankaj Kumar, Kadoorie Farm and Botanic Garden Corporation, Hong Kong S.A.R., China

Dr. V. Sampath Kumar, Botanical Survey of India, Howrah, West Bengal, India

Dr. A.J. Solomon Raju, Andhra University, Visakhapatnam, India

Dr. Vijayasankar Raman, University of Mississippi, USA

Dr. B. Ravi Prasad Rao, Sri Krishnadevaraya University, Anantpur, India

Dr. K. Ravikumar, FRLHT, Bengaluru, Karnataka, India

Dr. Aparna Watve, Pune, Maharashtra, India

Dr. Qiang Liu, Xishuangbanna Tropical Botanical Garden, Yunnan, China

Dr. Noor Azhar Mohamed Shazili, Universiti Malaysia Terengganu, Kuala Terengganu, Malaysia

Dr. M.K. Vasudeva Rao, Shiv Ranjani Housing Society, Pune, Maharashtra, India

Prof. A.J. Solomon Raju, Andhra University, Visakhapatnam, India

Dr. Mandar Datar, Agharkar Research Institute, Pune, Maharashtra, India

Dr. M.K. Janarthanam, Goa University, Goa, India

Dr. K. Karthigeyan, Botanical Survey of India, India

Dr. Errol Vela, University of Montpellier, Montpellier, France

Dr. P. Lakshminarasimhan, Botanical Survey of India, Howrah, India

Dr. Larry R. Noblick, Montgomery Botanical Center, Miami, USA

Dr. K. Haridasan, Pallavur, Palakkad District, Kerala, India

Dr. Analinda Manila-Fajard, University of the Philippines Los Banos, Laguna, Philippines

Dr. P.A. Sinu, Central University of Kerala, Kasaragod, Kerala, India

Dr. Afroz Alam, Banasthali Vidyapith (accredited A grade by NAAC), Rajasthan, India

Dr. K.P. Rajesh, Zamorin's Guruvayurappan College, GA College PO, Kozhikode, Kerala, India

Dr. David E. Boufford, Harvard University Herbaria, Cambridge, MA 02138-2020, USA

Dr. Ritesh Kumar Choudhary, Agharkar Research Institute, Pune, Maharashtra, India

Dr. Navendu Page, Wildlife Institute of India, Chandrabani, Dehradun, Uttarakhand, India

\section{Invertebrates}

Dr. R.K. Avasthi, Rohtak University, Haryana, India

Dr. D.B. Bastawade, Maharashtra, India

Dr. Partha Pratim Bhattacharjee, Tripura University, Suryamaninagar, India

Dr. Kailash Chandra, Zoological Survey of India, Jabalpur, Madhya Pradesh, India

Dr. Ansie Dippenaar-Schoeman, University of Pretoria, Queenswood, South Africa

Dr. Rory Dow, National Museum of natural History Naturalis, The Netherlands

Dr. Brian Fisher, California Academy of Sciences, USA

Dr. Richard Gallon, llandudno, North Wales, LL30 1UP

Dr. Hemant V. Ghate, Modern College, Pune, India

Dr. M. Monwar Hossain, Jahangirnagar University, Dhaka, Bangladesh

Mr. Jatishwor Singh Irungbam, Biology Centre CAS, Branišovská, Czech Republic.

Dr. Ian J. Kitching, Natural History Museum, Cromwell Road, UK

Dr. George Mathew, Kerala Forest Research Institute, Peechi, India

For Focus, Scope, Aims, and Policies, visit https://threatenedtaxa.org/index.php/JoTT/aims_scope
For Article Submission Guidelines, visit https://threatenedtaxa.org/index.php/JoTT/about/submissions
For Policies against Scientific Misconduct, visit https://threatenedtaxa.org/index.php/JoTT/policies_various

continued on the back inside cover 


\title{
Study on incidence and pathology of gastrointestinal parasitic infections in Nilgai Boselaphus tragocamelus in Hisar, Haryana, India
}

\author{
Maneesh Sharma ${ }^{1} \mathbb{D}$, B.L. Jangir ${ }^{2} \mathbb{D}$, D. Lather ${ }^{3} \mathbb{D}$, G.A. Chandratre ${ }^{4} \mathbb{D}$, V. Nehra ${ }^{5} \mathbb{D}$, K.K. Jakhar ${ }^{6} \mathbb{D} \&$ \\ G. Narang ${ }^{7}$ (iD \\ ${ }^{1}$ Department of Veterinary Clinical Complex, ${ }^{2-7}$ Department of Veterinary Pathology, \\ College of Veterinary Sciences, Lala Lajpat Rai University of Veterinary and Animal Sciences (LUVAS) Hisar, Haryana 125004, India. \\ ${ }^{1}$ drmaneeshvet@gmail.com (corresponding author), ${ }^{2}$ drbabu.jangir@gmail.com, ${ }^{3}$ deepikalather@yahoo.co.in, \\ ${ }^{4}$ drgaurichandratre@gmail.com, ${ }^{5}$ drvikasnehra@gmail.com, ${ }^{6}$ kk_hau@rediffmail.com, ${ }^{7}$ gulshan.narang@gmail.com
}

India has a diverse population of domestic and wildlife animals that are either kept in captivity or in free range. Among them, Blue Bull, commonly called Nilgai in India, is one of the most commonly observed wild animals in agriculture dominated landscapes in central and northern India (Meena et al. 2014). The main threat for the existence of this species is the loss of their habitat due to human population growth, encroachment of forests and emergence of wildlife diseases. Several studies of wild life diseases especially parasitic diseases have been carried out in wild animals including nilgai species (Banerjee et al. 2005) and a number of helminths, arthropods and protozoan parasites were reported. In wild conditions, animals have some natural resistance against parasitic diseases and there is a state of equilibrium between the parasite and the host and it seldom led to harmful infection unless stressed (Gaur et al. 1979; Mir et al. 2016). In India, studies to assess helminth fauna of wild animals under captivity were carried out in a systematic way but the literature on the parasitic infections of free ranging wild animals is very scanty because of the difficulty in collection of fresh samples from these free ranging wild animals. The samples collected during postmortem cases may contribute in a better understanding of parasitic load as well as pathology caused by them to formulate different strategies in the control of different parasitic diseases.

Study area: The present study was conducted in the Department of Veterinary Pathology, Lala Lajpat Rai University of Veterinary and Animal Sciences (LUVAS), Hisar. The Hisar district of Haryana is located between 29.151 latitude, 75.721 longitude and $215.5 \mathrm{~m}$ altitude. The climate of Hisar region is continental and it lies at the outer margins of the monsoon region, 1,600 km away from the ocean. The average maximum and minimum temperature during the month of March is $31.5^{\circ} \mathrm{C}$ and $16.4^{\circ} \mathrm{C}$. The average annual rainfall in the district is 455 $\mathrm{mm}$ (Central Ground Water Board 2017).

Collection and processing of the samples: A total of 20 carcasses of Nilgai were brought to the Department

Citation: Sharma, M., B.L. Jangir, D. Lather, G.A. Chandratre, V. Nehra, K.K. Jakhar \& G. Narang (2021). Study on incidence and pathology of gastrointestinal parasitic infections in Nilgai Boselaphus tragocamelus in Hisar, Haryana, India. Journal of Threatened Taxa 13(13): 20124-20127. https://doi.org/10.11609/ jott.6674.13.13.20124-20127

Copyright: (C) Sharma et al. 2021. Creative Commons Attribution 4.0 International License. JoTT allows unrestricted use, reproduction, and distribution of this article in any medium by providing adequate credit to the author(s) and the source of publication.

Funding: None.

Competing interests: The authors declare no conflicts of interest with respect to the research, authorship, and/or publication of this present article.

Ethical approval: In the present article, samples are taken from the dead carcasses of Nilgai brought to Veterinary Pathology for complete postmortem examination. Hence, it does not need any ethical approval and is not under consideration elsewhere and none of the paper's contents have been previously published.

Acknowledgements: Authors are thankful to Head, Veterinary Pathology of College of Veterinary Sciences, Lala Lajpat Rai University of Veterinary and Animal Sciences, Hisar for providing necessary facilities for carrying out the present study. 
of Veterinary Pathology for necropsy by Wild Life Department, Hisar, from Hisar district and surrounding areas. Intestinal contents and faecal samples were collected in sterile polythene bags, properly sealed, labelled and processed for detailed routine parasitological analysis for the presence of parasitic eggs/oocysts by direct smear method and standard flotation technique using a saturated salt solution and sedimentation method.

Pathological studies: The detailed gross pathological examination was carried out and lesions were recorded. For histopathology, the representative tissue samples of intestine were collected in 10\% neutral buffered formalin. After proper fixation, tissue samples were processed for histopathological examination. The tissues were properly trimmed, washed in running tap water over night, then dehydrated in ascending grades of ethanol, cleared in xylene and then embedded in paraffin wax. Sections of 4-5 $\mu \mathrm{m}$ thickness were cut using a semi-automatic rotary microtome. Thereafter, the sections were stained with haematoxylin and eosin (H\&E) as per standard procedure (Luna 1968).

Results: During necropsy, the external examination of most of the carcasses showed varying degrees of traumatic injuries (9), external wounds and haemorrhages (5) along with putrefactive changes (6). Grossly, intestines revealed reddish discoloration, thickened mucosa and the presence of catarrhal exudate (Image 1). All 20 faecal samples were screened for the presence of gastrointestinal helminthsand protozoan infections. Overall the incidence of parasitic gastrointestinal tract infection was $40 \%$ (8/20). All eight cases revealed the presence of coccidian oocysts (Image 2), along with mixed infection with one or more types of helminthic eggs in two samples. All coccidian infections were found to be caused by Eimeria species by using sporulation technique. Among helminthic infections, Strongyle, Moneizia and Trichuris spp. were observed. Faecal samples showed unsporulated oocysts of Eimeria spp., thin double walled, smooth colourless eggs of Strongyle spp. containing blastomere (Image 2), eggs of Moneizia spp. containing a distinct pyriform apparatus (Image 3) and yellowish-brown, barrel shaped thick walled eggs of Trichuris spp. (Image 4) possessing a pair of polar plugs at both ends and egg mass identified by morphological characteristics. The results of faecal sample examination are presented in Table 1 and 2 . Microscopic examination of intestine revealed congested mucosal and submucosal blood vessels, fusion of villi and desquamation of mucosal epithelium in focal areas (Image 5). Intestinal mucosa also revealed moderate
Table 1.Incidence of parasitic infection in Blue Bull / Nilgai ( $N=20$ faecal samples).

\begin{tabular}{|l|c|}
\hline Oocysts/ Eggs of parasites observed & Number of samples \\
\hline Coccidian oocysts (Eimeria spp.) & 06 \\
\hline $\begin{array}{l}\text { Mixed infection (Eimeriaspp. + Moneizia spp. } \\
\text { +Strongyle spp.) }\end{array}$ & 01 \\
\hline $\begin{array}{l}\text { Mixed infection (Eimeriaspp. + Strongyle spp. + } \\
\text { Trichuris spp.) }\end{array}$ & 01 \\
\hline No parasitic infection & 12 \\
\hline Total & $\mathbf{2 0}$ \\
\hline
\end{tabular}

Table 2. Semi quantitative load of parasitic eggs/oocysts in Nilgai.

\begin{tabular}{|c|c|c|c|c|c|}
\hline & \multirow[t]{2}{*}{ Sample } & \multicolumn{4}{|c|}{ Parasitic load } \\
\hline & & $\begin{array}{c}\text { Eimeria } \\
\text { spp. }\end{array}$ & $\begin{array}{c}\text { Moneizia } \\
\text { spp. }\end{array}$ & $\begin{array}{c}\text { Strongyle } \\
\text { spp. }\end{array}$ & $\begin{array}{c}\text { Trichuris } \\
\text { spp. }\end{array}$ \\
\hline 1 & N1 & - & - & - & - \\
\hline 2 & N2 & - & - & - & - \\
\hline 3 & N3 & - & - & - & - \\
\hline 4 & N4 & - & - & - & - \\
\hline 5 & N5 & - & - & - & - \\
\hline 6 & N6 & ++ & ++ & +++ & - \\
\hline 7 & N7 & - & - & - & - \\
\hline 8 & N8 & +++ & - & ++ & + \\
\hline 9 & N9 & - & - & - & - \\
\hline 10 & N10 & - & - & - & - \\
\hline 11 & N11 & ++ & - & - & - \\
\hline 12 & $\mathrm{~N} 12$ & ++ & - & - & - \\
\hline 13 & N13 & ++ & - & - & - \\
\hline 14 & N14 & +++ & - & - & - \\
\hline 15 & N15 & ++ & - & - & - \\
\hline 16 & N16 & + & - & - & - \\
\hline 17 & N17 & - & - & - & - \\
\hline 18 & N18 & - & - & - & - \\
\hline 19 & N19 & - & - & - & - \\
\hline 20 & N2O & - & - & - & - \\
\hline
\end{tabular}

--No egg/oocyst | +-Mild load | ++-Moderate load | +++-Heavy load.

infiltration of mononuclear cells mainly lymphocytes in the lamina propria along with different developmental stages of coccidian oocysts (Image 6).

Discussion: Wild animals are important reservoirs and amplifiers of emerging human and domestic animal pathogens including parasitic infections. In addition to their well-recognized zoonoses of public health significance, wildlife has gained considerable attention in recent years. Parasitic infections are quite common in wild ruminants across India (Banerjee et al. 2005). These 


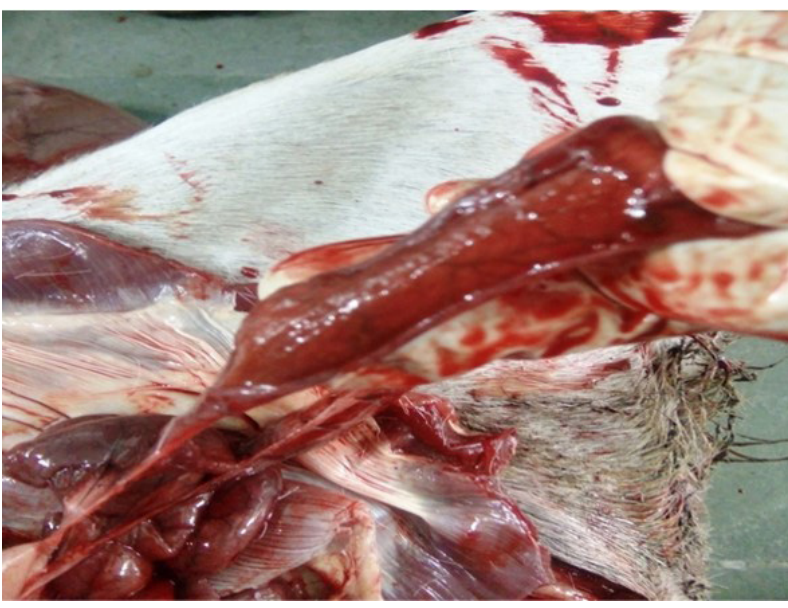

Image 1. Gross examination of intestine revealed congestion, haemorrhages, thickened mucosa and presence of catarrhal exudates.

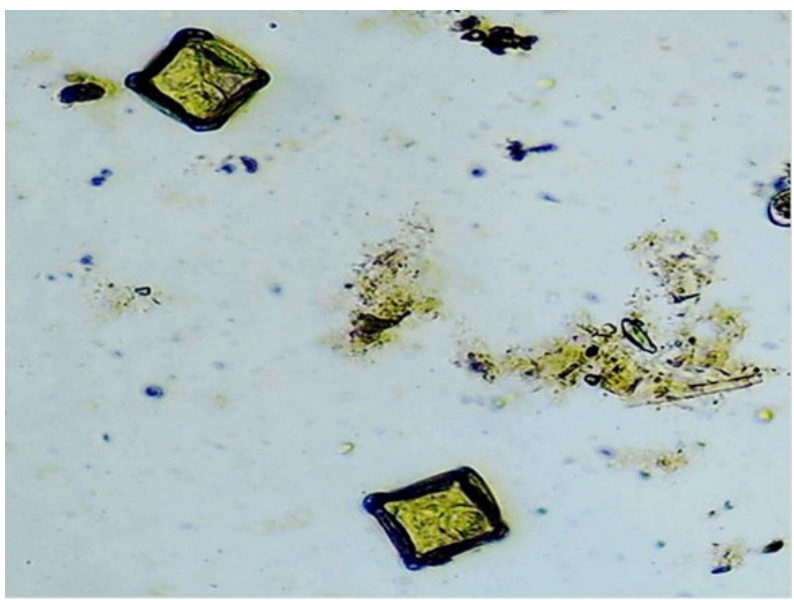

Image 3. Faecal sample showing square eggs of Moneizia spp. containing a distinct pyriform apparatus. $X 400$.

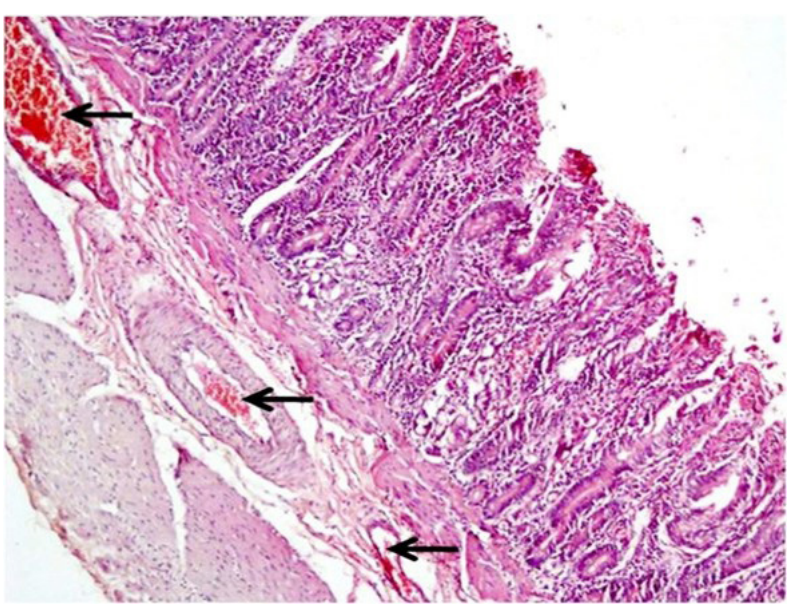

Image 5. Section of intestine showing congestion (arrows), fused villi, desquamated mucosal epithelium in focal areas and infiltration of mononuclear cells mainly lymphocytes. H\&E X 100

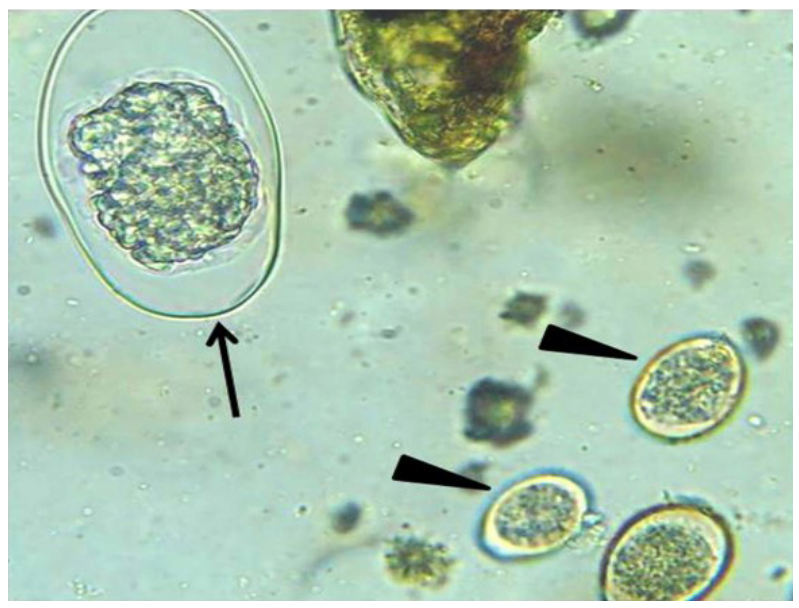

Image 2. Faecal sample showing thin double walled, smooth colourless barrel shaped egg of Strongyle spp. containing blastomere (arrow) and unsporulated oocysts of Eimeriaspp. (arrow heads). X 400.

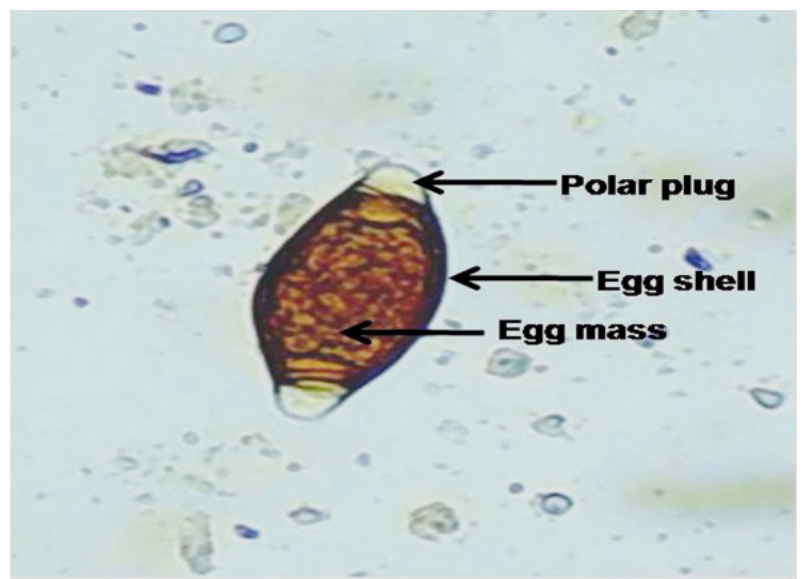

Image 4. Faecal sample showing barrel shaped thick walled eggs of Trichuris spp. possessing a pair of polar plugs at both ends and egg mass. $X 400$

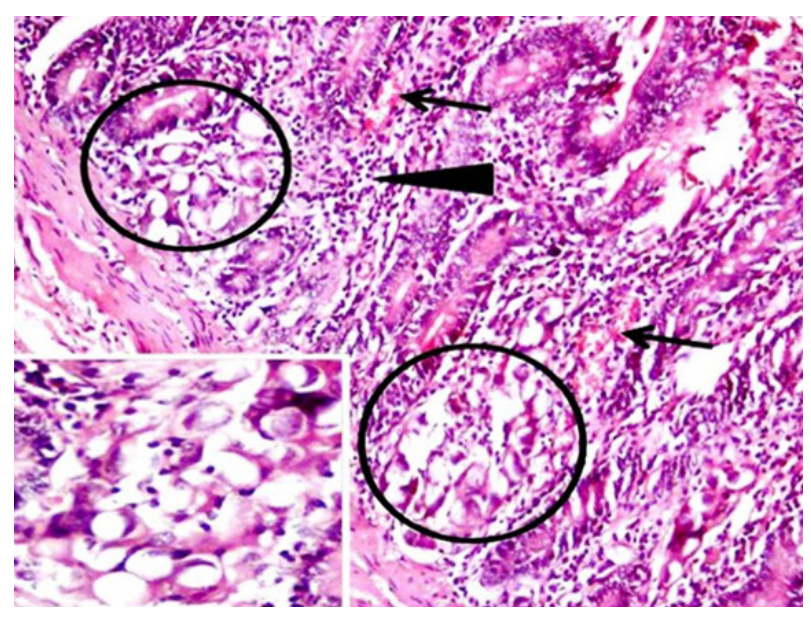

Image 6. Section of intestine showing congestion (arrow) of intestinal mucosa revealed moderate infiltration of mononuclear cells mainly lymphocytes (arrow) and different stages of developmental stages of coccidian oocysts (encircled). H\&E X 400. 
animals may acquire large quantums of infection while grazing that are mostly subclinical. However, sometimes the infections turn fatal for the infected animal. In the present study, most of the carcasses of Nilgai examined showed varying degrees of traumatic injuries, external wounds and haemorrhages and putrefactive changes. The main reason for the death of the animals is due to accidental injuries from vehicles on the roads and the use of barbed wires by farmers for fencing to protect agricultural land. However, this can be minimized by use of alternative methods of fencing to protect crop damage (Meena et al. 2014). The extent of injuries varied from bruises, lacerations and single to multiple fractures cases. Similar finding of varying degrees of more or less traumatic injuries caused by bullets/gunshots, infighting, automobile/train accidents, jumping/falling leading to haemorrhagic shock was also reported by Sharma et al. (2014).

As regard to parasitic infections, the morphological characteristics of the eggs of Strongyle spp., Moneizia spp., Trichuris spp., and coccidian oocysts was confirmed as per Soulsby (1982). Various studies of single and mixed parasitic infections in wild animals has also been reported by earlier researchers (Abhishek et al. 2011; Jaiswal et al. 2014). In Uttaranchal, India, 41.6\% of 161 faecal samples from Nilgai were positive for single or mixed infections of Amphistomes, Strongyles, Trichuris, Fasciola, and coccidians (Banerjee et al. 2005). Endoparasitic fauna in wild animals and consequent detection of infection in these wild animals suggests close interactions with domestic animals (Holsback et al. 2013). Sharing of the same pasture land and water bodies like ponds by wild and domestic animals might be a potential source of infection for domestic animals. Histopathologically, intestines revealed circulatory disturbances such as congestion, enteritis and different developmental stages particularly in coccidian infected cases. Similar findings were also observed in Nilgai by other researchers (Sharma et al. 2012). In the present study, different types of mixed parasitic infections in free ranging nilgai with gross and microscopic changes in the intestinal tracts indicate that the increase in parasitic load might be due to the secondary infestation by opportunistic parasites due to decreased immune response because of stressful environmental conditions or injuries. Further, more detailed studies will be required as wild herbivores not only come into close contact with different domestic animals, but share the same pasture for grazing that might cause potential threat of interspecies transmission. This will also be of great importance for species conservation.

\section{References}

Banerjee, P.S., R. Garg, C.L. Yadav \& D.H. Ram (2005). Parasitic infections in some wild animals of Uttaranchal. Indian Journal of Animal Sciences 75: 206-208.

Central Ground Water Board (2017). Aquifer mapping and management plan. Hisar District, Haryana, 128 pp. http://cgwb.gov. in/

Gaur, S.N.S., M.S. Sethi, H.C. Tewari \& O. Prakash (1979). A note on the prevalence of helminth parasites in wild and zoo animals in Uttar Pradesh. Indian Journal of Animal Sciences 46: 159-161.

Gupta, A., A.K. Dixit, P. Dixit, C. Mahajan \& A.B. Shrivastava (2011). Incidence of gastro-intestinal parasites in wild ruminants around Jabalpur, India. Journal of Threatened Taxa 3(11): 2226-2228. https://doi.org/10.11609/JoTT. 02431.2226-8

Holsback, L., M.J.L. Cardoso, R. Fagnani, \& T.H.C. Patelli (2013). Natural infection by endo-parasites among free-living wild animals. Brazilian Journal of Veterinary Parasitology 22(2): 302-306. https:// doi.org/10.1590/S1984-29612013005000018

Jaiswal, A.K., A., Srivastava, V. Sudan, R. Singh, D. Shanker\& R. Parashar (2014). Prevalence of endoparasitic infections in wild cervids of Army Golf Course, Mathura. Journal of Parasitic Diseases 38(4): 358-360. https://doi.org/10.1007/s12639-0130248-y

Luna, L.G. (1968). Manual of Histologic Staining Methods of the Armed Forces Institute of Pathology - $3^{\text {rd }}$ Edition. McGraw Hill Book Company, New York.

Meena, R.P., B.L. Meena, U. Nandal \& C.L. Meena (2014). Indigenous measures developed by farmers to curb the menace of blue bull (Boselaphus tragocamelus) in district Rajsamand, Rajasthan, India. Indian Journal of Traditional Knowledge13(1): 208-215.

Mir, A.Q., K. Dua, L.D. Singla, S. Sharma \& M.P. Singh (2016). Prevalence of parasitic infection in captive wild animals in Bir Moti Bagh mini zoo (Deer Park), Patiala, Punjab. Veterinary World 9(6): 540-543. https://doi.org/10.14202/vetworld.2016.540-543

Sharma, A.K., N. Shivasharanappa, P.S. Banerjee, M. Sahini, S.S. Raut, G.A. Chandratre \& A. Das (2012). Intestinal Coccidiosis in a Nilgai calf (Boselaphus tragocamelus). India Journal of Veterinary Pathology 36(2):266-268.

Sharma, A.K., N. Shivasharanappa, G.A. Chandratre, M. Sahini, A. Das, S.S. Raut, D. Swarup \& R. Somvanshi (2014). Prevalence of pathological conditions in zoo/wild animals in India: aretrospective study based on necropsy. Proceedings of the National Academy of Sciences, India, Section B: Biological Sciences. 84(4):937-946. https://doi.org/10.1007/s40011-014-0308-9

Soulsby, E.J.L. (1982). Helminths, Arthropods and Protozoa of Domesticated Animals. $7^{\text {th }}$ edition. Bailliere Tindall, London, 809pp. 
Dr. John Noyes, Natural History Museum, London, UK

Dr. Albert G. Orr, Griffith University, Nathan, Australia

Dr. Sameer Padhye, Katholieke Universiteit Leuven, Belgium

Dr. Nancy van der Poorten, Toronto, Canada

Dr. Kareen Schnabel, NIWA, Wellington, New Zealand

Dr. R.M. Sharma, (Retd.) Scientist, Zoological Survey of India, Pune, India

Dr. Manju Siliwal, WILD, Coimbatore, Tamil Nadu, India

Dr. G.P. Sinha, Botanical Survey of India, Allahabad, India

Dr. K.A. Subramanian, Zoological Survey of India, New Alipore, Kolkata, India

Dr. P.M. Sureshan, Zoological Survey of India, Kozhikode, Kerala, India

Dr. R. Varatharajan, Manipur University, Imphal, Manipur, India

Dr. Eduard Vives, Museu de Ciències Naturals de Barcelona, Terrassa, Spain

Dr. James Young, Hong Kong Lepidopterists' Society, Hong Kong

Dr. R. Sundararaj, Institute of Wood Science \& Technology, Bengaluru, India

Dr. M. Nithyanandan, Environmental Department, La Ala Al Kuwait Real Estate. Co. K.S.C.,

Kuwait

Dr. Himender Bharti, Punjabi University, Punjab, India

Mr. Purnendu Roy, London, UK

Dr. Saito Motoki, The Butterfly Society of Japan, Tokyo, Japan

Dr. Sanjay Sondhi, TITLI TRUST, Kalpavriksh, Dehradun, India

Dr. Nguyen Thi Phuong Lien, Vietnam Academy of Science and Technology, Hanoi, Vietnam

Dr. Nitin Kulkarni, Tropical Research Institute, Jabalpur, India

Dr. Robin Wen Jiang Ngiam, National Parks Board, Singapore

Dr. Lional Monod, Natural History Museum of Geneva, Genève, Switzerland.

Dr. Asheesh Shivam, Nehru Gram Bharti University, Allahabad, India

Dr. Rosana Moreira da Rocha, Universidade Federal do Paraná, Curitiba, Brasi

Dr. Kurt R. Arnold, North Dakota State University, Saxony, Germany

Dr. James M. Carpenter, American Museum of Natural History, New York, USA

Dr. David M. Claborn, Missouri State University, Springfield, USA

Dr. Kareen Schnabel, Marine Biologist, Wellington, New Zealand

Dr. Amazonas Chagas Júnior, Universidade Federal de Mato Grosso, Cuiabá, Brasil

Mr. Monsoon Jyoti Gogoi, Assam University, Silchar, Assam, India

Dr. Heo Chong Chin, Universiti Teknologi MARA (UiTM), Selangor, Malaysia

Dr. R.J. Shiel, University of Adelaide, SA 5005, Australia

Dr. Siddharth Kulkarni, The George Washington University, Washington, USA

Dr. Priyadarsanan Dharma Rajan, ATREE, Bengaluru, India

Dr. Phil Alderslade, CSIRO Marine And Atmospheric Research, Hobart, Australia

Dr. John E.N. Veron, Coral Reef Research, Townsville, Australia

Dr. Daniel Whitmore, State Museum of Natural History Stuttgart, Rosenstein, Germany.

Dr. Yu-Feng Hsu, National Taiwan Normal University, Taipei City, Taiwan

Dr. Keith V. Wolfe, Antioch, California, USA

Dr. Siddharth Kulkarni, The Hormiga Lab, The George Washington University, Washington,

D.C., USA

Dr. Tomas Ditrich, Faculty of Education, University of South Bohemia in Ceske

Budejovice, Czech Republic

Dr. Mihaly Foldvari, Natural History Museum, University of Oslo, Norway

Dr. V.P. Uniyal, Wildlife Institute of India, Dehradun, Uttarakhand 248001, India

Dr. John T.D. Caleb, Zoological Survey of India, Kolkata, West Bengal, India

Dr. Priyadarsanan Dharma Rajan, Ashoka Trust for Research in Ecology and the Environment

(ATREE), Royal Enclave, Bangalore, Karnataka, India

\section{Fishes}

Dr. Neelesh Dahanukar, IISER, Pune, Maharashtra, India

Dr. Topiltzin Contreras MacBeath, Universidad Autónoma del estado de Morelos, México

Dr. Heok Hee Ng, National University of Singapore, Science Drive, Singapore

Dr. Rajeev Raghavan, St. Albert's College, Kochi, Kerala, India

Dr. Robert D. Sluka, Chiltern Gateway Project, A Rocha UK, Southall, Middlesex, UK

Dr. E. Vivekanandan, Central Marine Fisheries Research Institute, Chennai, India

Dr. Davor Zanella, University of Zagreb, Zagreb, Croatia

Dr. A. Biju Kumar, University of Kerala, Thiruvananthapuram, Kerala, India

Dr. Akhilesh K.V., ICAR-Central Marine Fisheries Research Institute, Mumbai Research

Centre, Mumbai, Maharashtra, India

Dr. J.A. Johnson, Wildlife Institute of India, Dehradun, Uttarakhand, India

Amphibians

Dr. Sushil K. Dutta, Indian Institute of Science, Bengaluru, Karnataka, India

Dr. Annemarie Ohler, Muséum national d'Histoire naturelle, Paris, France

\section{Reptiles}

Dr. Gernot Vogel, Heidelberg, Germany

Dr. Raju Vyas, Vadodara, Gujarat, India

Dr. Pritpal S. Soorae, Environment Agency, Abu Dubai, UAE.

Prof. Dr. Wayne J. Fuller, Near East University, Mersin, Turkey

Prof. Chandrashekher U. Rivonker, Goa University, Taleigao Plateau, Goa. India

Dr. S.R. Ganesh, Chennai Snake Park, Chennai, Tamil Nadu, India

Dr. Himansu Sekhar Das, Terrestrial \& Marine Biodiversity, Abu Dhabi, UAE
Birds

Dr. Hem Sagar Baral, Charles Sturt University, NSW Australia

Dr. Chris Bowden, Royal Society for the Protection of Birds, Sandy, UK

Dr. Priya Davidar, Pondicherry University, Kalapet, Puducherry, India

Dr. J.W. Duckworth, IUCN SSC, Bath, UK

Dr. Rajah Jayapal, SACON, Coimbatore, Tamil Nadu, India

Dr. Rajiv S. Kalsi, M.L.N. College, Yamuna Nagar, Haryana, India

Dr. V. Santharam, Rishi Valley Education Centre, Chittoor Dt., Andhra Pradesh, India

Dr. S. Balachandran, Bombay Natural History Society, Mumbai, India

Mr. J. Praveen, Bengaluru, India

Dr. C. Srinivasulu, Osmania University, Hyderabad, India

Dr. K.S. Gopi Sundar, International Crane Foundation, Baraboo, USA

Dr. Gombobaatar Sundev, Professor of Ornithology, Ulaanbaatar, Mongolia

Prof. Reuven Yosef, International Birding \& Research Centre, Eilat, Israel

Dr. Taej Mundkur, Wetlands International, Wageningen, The Netherlands

Dr. Carol Inskipp, Bishop Auckland Co., Durham, UK

Dr. Tim Inskipp, Bishop Auckland Co, Durham, UK

Dr. V. Gokula, National College, Tiruchirappalli, Tamil Nadu, India

Dr. Arkady Lelej, Russian Academy of Sciences, Vladivostok, Russia

Dr. Simon Dowell, Science Director, Chester Zoo, UK

Dr. Mário Gabriel Santiago dos Santos, Universidade de Trás-os-Montes e Alto Douro,

Quinta de Prados, Vila Real, Portugal

Dr. Grant Connette, Smithsonian Institution, Royal, VA, USA

Dr. M. Zafar-ul Islam, Prince Saud Al Faisal Wildlife Research Center, Taif, Saudi Arabia

Mammals

Dr. Giovanni Amori, CNR - Institute of Ecosystem Studies, Rome, Italy

Dr. Anwaruddin Chowdhury, Guwahati, India

Dr. David Mallon, Zoological Society of London, UK

Dr. Shomita Mukherjee, SACON, Coimbatore, Tamil Nadu, India

Dr. Angie Appel, Wild Cat Network, Germany

Dr. P.O. Nameer, Kerala Agricultural University, Thrissur, Kerala, India

Dr. Ian Redmond, UNEP Convention on Migratory Species, Lansdown, UK

Dr. Heidi S. Riddle, Riddle's Elephant and Wildlife Sanctuary, Arkansas, USA

Dr. Karin Schwartz, George Mason University, Fairfax, Virginia.

Dr. Lala A.K. Singh, Bhubaneswar, Orissa, India

Dr. Mewa Singh, Mysore University, Mysore, India

Dr. Paul Racey, University of Exeter, Devon, UK

Dr. Honnavalli N. Kumara, SACON, Anaikatty P.O., Coimbatore, Tamil Nadu, India

Dr. Nishith Dharaiya, HNG University, Patan, Gujarat, India

Dr. Spartaco Gippoliti, Socio Onorario Società Italiana per la Storia della Fauna "Giuseppe

Altobello", Rome, Italy

Dr. Justus Joshua, Green Future Foundation, Tiruchirapalli, Tamil Nadu, India

Dr. H. Raghuram, The American College, Madurai, Tamil Nadu, India

Dr. Paul Bates, Harison Institute, Kent, UK

Dr. Jim Sanderson, Small Wild Cat Conservation Foundation, Hartford, USA

Dr. Dan Challender, University of Kent, Canterbury, UK

Dr. David Mallon, Manchester Metropolitan University, Derbyshire, UK

Dr. Brian L. Cypher, California State University-Stanislaus, Bakersfield, CA

Dr. S.S. Talmale, Zoological Survey of India, Pune, Maharashtra, India

Prof. Karan Bahadur Shah, Budhanilakantha Municipality, Kathmandu, Nepal

Dr. Susan Cheyne, Borneo Nature Foundation International, Palangkaraja, Indonesia

Dr. Hemanta Kafley, Wildlife Sciences, Tarleton State University, Texas, USA

\section{Other Disciplines}

Dr. Aniruddha Belsare, Columbia MO 65203, USA (Veterinary)

Dr. Mandar S. Paingankar, University of Pune, Pune, Maharashtra, India (Molecular)

Dr. Jack Tordoff, Critical Ecosystem Partnership Fund, Arlington, USA (Communities)

Dr. Ulrike Streicher, University of Oregon, Eugene, USA (Veterinary)

Dr. Hari Balasubramanian, EcoAdvisors, Nova Scotia, Canada (Communities)

Dr. Rayanna Hellem Santos Bezerra, Universidade Federal de Sergipe, São Cristóvão, Brazil

Dr. Jamie R. Wood, Landcare Research, Canterbury, New Zealand

Dr. Wendy Collinson-Jonker, Endangered Wildlife Trust, Gauteng, South Africa

Dr. Rajeshkumar G. Jani, Anand Agricultural University, Anand, Gujarat, India

Dr. O.N. Tiwari, Senior Scientist, ICAR-Indian Agricultural Research Institute (IARI), New

Delhi, India

Dr. L.D. Singla, Guru Angad Dev Veterinary and Animal Sciences University, Ludhiana, India

Dr. Rupika S. Rajakaruna, University of Peradeniya, Peradeniya, Sri Lanka

Dr. Bahar Baviskar, Wild-CER, Nagpur, Maharashtra 440013, India

Reviewers 2018-2020

Due to pausity of space, the list of reviewers for $2018-2020$ is available online.

The opinions expressed by the authors do not reflect the views of the Journal of Threatened Taxa, Wildlife Information Liaison Development Society, Zoo Outreach Organization, or any of the partners. The journal, the publisher, the host, and the partners are not responsible for the accuracy of the political boundaries shown in the maps by the authors.

Journal of Threatened Taxa is indexed/abstracted in Bibliography of Systematic Mycology, Biological Abstracts, BIOSIS Previews, CAB Abstracts, EBSCO, Google Scholar, Index Copernicus, Index Fungorum, JournalSeek, National Academy of Agricultural Sciences, NewJour, OCLC WorldCat, SCOPUS, Stanford University Libraries, Virtual Library of Biology, Zoological Records.

NAAS rating (India) 5.64
Print copies of the Journal are available at cost. Write to:

The Managing Editor, JoTT,

c/o Wildlife Information Liaison Development Society,

No. 12, Thiruvannamalai Nagar, Saravanampatti - Kalapatti Road,

Saravanampatti, Coimbatore, Tamil Nadu 641035, India

ravi@threatenedtaxa.org 


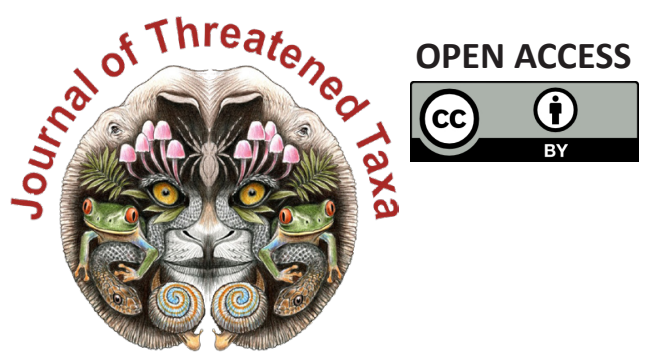

www.threatenedtaxa.org

The Journal of Threatened Taxa (JoTT) is dedicated to building evidence for conservation globally by publishing peer-reviewed articles online every month at a reasonably rapid rate at www.threatenedtaxa.org. All articles published in JoTT are registered under Creative Commons Attribution 4.0 International License unless otherwise mentioned. JoTT allows allows unrestricted use, reproduction, and distribution of articles in any medium by providing adequate credit to the author(s) and the source of publication.

ISSN 0974-7907 (Online) I ISSN $0974-7893$ (Print)

\section{November 2021 | Vol. 13 | No. 13 | Pages: 19887-20142 \\ Date of Publication: 26 November 2021 (Online \& Print) DOI: 10.11609/jott.2021.13.13.19887-20142}

\section{Article}

An inventory of geometrid moths (Lepidoptera: Geometroidea: Geometridae) of KalakadMundanthurai Tiger Reserve, India

- Geetha Iyer, Dieter Stüning \& Sanjay Sondhi, Pp. 19887-19920

\section{Communications}

Roadkills of Lowland Tapir Tapirus terrestris (Mammalia: Perissodactyla: Tapiridae) in one of its last refuges in the Atlantic Forest

- Aureo Banhos, Andressa Gatti, Marcelo Renan de Deus Santos, Leonardo Merçon,

Ilka Westermeyer, Natália Carneiro Ardente, Luis Francisco Oliveira Pereira Gonzaga, Lucas Mendes Barreto, Lucas Damásio, Tomas Lima Rocha, Vitor Roberto Schettino, Renata Valls, Helena Godoy Bergallo, Marcos Vinicius Freitas Silva, Athelson Stefanon Bittencourt, Danielle de Oliveira Moreira \& Ana Carolina Srbek-Araujo, Pp. 19921-19929

Scientific contributions and learning experiences of citizen volunteers with a small cat project in Sanjay Gandhi National Park, Mumbai, India

- Shomita Mukherjee, R. Nandini, P.V. Karunakaran \& Nayan Khanolkar, Pp. 19930-19936

Seasonal food preferences and group activity pattern of Blackbuck Antilope cervicapra (L., 1758) (Mammalia: Cetartiodactyla: Bovidae) in a semi-arid region of western Haryana, India

- Vikram Delu, Dharambir Singh, Sumit Dookia, Priya \& Kiran, Pp. 19937-19947

Studies on the habitats of Grey Francolin Francolinus pondicerianus (J.F. Gmelin, 1789) (Galliformes: Phasianidae) in northern districts of Tamil Nadu, India

- M. Pandian, Pp. 19948-19955

Recovery of vulture population in roosting and scavenging areas of Bastar and Bijapur, Chhattisgarh, India

- Sushil Kumar Dutta, Muntaz Khan, P.R.S. Nagi, Santosh Durgam \& Surabhi Dutta, Pp. 19956-19963

A geographical assessment of Chariganga and Arpara Beel (wetlands) of Nadia, West Bengal as a habitat of wetland birds

- Mehedi Hasan Mandal, Arindam Roy \& Giyasuddin Siddique, Pp. 19964-19975

Phenotypic plasticity in Barilius vagra (Hamilton, 1822) (Teleostei: Danionidae) from two geographically distinct river basins of Indian Himalaya

- Sumit Kumar, Sharali Sharma \& Deepak Singh, Pp. 19976-19984

Taxonomic notes, a new species, and a key to Indian species of the click beetle genus Cryptalaus Ôhira, 1967 (Coleoptera: Elateridae: Agrypninae)

- Harshad Parekar \& Amol Patwardhan, Pp. 19985-19999

Niche overlap of benthic macrofauna in a tropical estuary: diurnal variation

- Mário Herculano de Oliveira, Lidiane Gomes de Lima, Caroline Stefani da Silva Lima, Jéssica de Oliveira Lima Gomes, Franciely Ferreira Paiva, Graciele de Barros, Carlinda Railly Medeiros \& Joseline Molozzi, Pp. 20000-20010

Diversity of aquatic insects and biomonitoring of water quality in the upper Ganga River, a Ramsar site: a preliminary assessment

- Kritish De, Arkojyoti Sarkar, Kritika Singh, Virendra Prasad Uniyal, Jeyaraj Antony Johnson \& Syed Ainul Hussain, Pp. 20011-20018

Patterns of forest cover loss in the terrestrial Key Biodiversity Areas in the Philippines: critical habitat conservation priorities

- Bernard Peter O. Daipan, Pp. 20019-20032

The woody flora of Shettihalli Wildlife Sanctuary, central Western Ghats of Karnataka, India - A checklist

- Kanda Naveen Babu, Kurian Ayushi, Vincy K. Wilson, Narayanan Ayyappan \&

Narayanaswamy Parthasarathy, Pp. 20033-20055

Reproductive biology of Ophiorrhiza caudata C.E.C.Fisch. (Rubiaceae), an endemic and endangered creeping perennial herb of the Western Ghats, India

- Maria Theresa, Appukuttan Kamalabai Sreekala \& Jayalakshmi Mohanlal, Pp. 20056-20065
Short Communications

Successful rescue, medical management, rehabilitation, and translocation of a Red Panda Ailurus fulgens (Mammalia: Carnivora: Ailuridae) in Arunachal Pradesh, India - Jahan Ahmed, Sorang Tadap, Millo Tasser, Koj Rinya, Nekibuddin Ahmed \& Sunil Kyarong, Pp. 20066-20071

A rare photographic record of Eurasian Otter Lutra lutra with a note on its habitat from the Bhagirathi Basin, western Himalaya, India

- Ranjana Pal, Aashna Sharma, Vineet Kumar Dubey, Tapajit Bhattacharya, Jeyaraj Antony Johnson, Kuppusamy Sivakumar \& Sambandam Sathyakumar, Pp. 20072-20077

The first record of Medog Gliding Frog Rhacophorus translineatus Wu, 1977 (Anura: Rhacophoridae) from Chhukha District, Bhutan

- Sonam Lhendup \& Bal Krishna Koirala, Pp. 20078-20083

First record of a freshwater crab, Maydelliathelphusa masoniana (Henderson, 1893) (Decapoda: Brachyura: Gecarcinucidae) from West Bengal, India

- Ram Krishna Das, Pp. 20084-20089

Butterflies of Amrabad Tiger Reserve, Telangana, India

- Deepa Jaiswal, B. Bharath, M. Karuthapandi, Shrikant Jadhav, S. Prabakaran \& S. Rehanuma Sulthana, Pp. 20090-20097

An enumeration of the flowering plants of Kyongnosla Alpine Sanctuary in eastern Sikkim, India

- Sudhansu Sekhar Dash, Subhajit Lahiri \& Ashiho Asoshii Mao, Pp. 20098-20117

A new record of psychrotrophic Paecilomyces formosus (Eurotiales: Ascomycota) from India: morphological and molecular characterization

- Skarma Nonzom \& Geeta Sumbali, Pp. 20118-20123

Notes

Study on incidence and pathology of gastrointestinal parasitic infections in Nilgai Boselaphus tragocamelus in Hisar, Haryana, India

- Maneesh Sharma, B.L. Jangir, D. Lather, G.A. Chandratre, V. Nehra, K.K. Jakhar \& G. Narang, Pp. 20124-20127

An unusual vocalization of Brown Hawk-Owl Ninox scutulata (Raffles, 1822) (Aves:

Strigiformes: Strigidae) recorded from Kerala, India

- Riju P. Nair \& Shine Raj Tholkudiyil, Pp. 20128-20129

New distribution data on the genus Maripanthus Maddison, 2020 (Araneae: Salticidae) from southern India

- A. Asima, John T.D. Caleb, Dhruv A. Prajapati \& G. Prasad, Pp. 20130-20132

On the IUCN status of Boesenbergia albolutea and B. rubrolutea (Zingiberaceae) and typification of $B$. rubrolutea

- K. Aishwarya \& M. Sabu, Pp. 20133-20135

New records of mass seeding Cephalostachyum latifolium Munro (Poaceae) along the midelevation broadleaved forest of Sarpang district, Bhutan

- Jigme Tenzin, Sangay Nidup \& Dago Dorji, Pp. 20136-20139

Response

If habitat heterogeneity is effective for conservation of butterflies in urban landscapes of Delhi, India?' Unethical publication based on data manipulation

- Sanjay Keshari Das \& Rita Singh, Pp. 20140-20142

Publisher \& Host
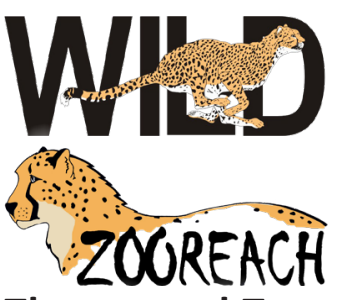

Threatened Taxa 